\title{
SISTEM INFORMASI PENGOLAHAN DATA TANAMAN HIAS DAN POHON PELINDUNG DI TAMAN KOTA PARIAMAN
}

\author{
Amalina 1), Sri Restu Ningsih ${ }^{2)}$, Nia Oktalina ${ }^{3)}$ \\ ${ }^{1,2,3}$ Sistem Informasi, STMIK Indonesia Padang, J1. Khatib Sulaiman Dalam No. 1. Padang \\ email: amalina@stmikindonesia.ac.id
}

\begin{abstract}
.
Pariaman city Department of Hygiene and Parks has a problem, ornamental trees are usually chosen for manual. So it can make a probability of mistake in choose ornamental trees. That effect is many plants can die because that plants doesn't have a good habitat. In additional, data reports are not well structured so it is neither effectife nor efficient. Because of that an information system for data processing of ornamental plants and shade trees in Pariaman City's gardens is build to help decision makers determining the type of plants and shade trees. This research is using System Development Life Cycle (SDLC), which consists of four main steps: planning, analysis, design and implementation, as well as the theories from the lectures and supporting books.
\end{abstract}

Keywords: Information Systems, ornamental plants, shade trees

\begin{abstract}
Abstrak.
Dinas Kebersihan dan Pertamanan Kota Pariaman memiliki permasalahan, yaitu penentuan jenis tanaman dan pohon pelindung secara manual masih memungkinkan terjadinya kesalahan dalam penentuan pemilihan tanaman yang menyebabkan tanaman mati karena tidak sesuai atau tidak cocok dengan kriteria tempat hidupnya. Laporan data belum terstruktur sehingga kurang efektif dan efisien. Untuk itu dibangun sebuah Sistem Informasi pengolahan data tanaman hias dan pohon pelindung di taman Kota Pariaman yang akan memudahkan pimpinan dalam menentukan jenis tanaman dan pohon pelindung. Skripsi ini menggunakan metode System Development Life Cycle (SDLC) yang terdiri dari empat langkah utama, yaitu perencanaan, analisis, perancangan, dan implementasi, serta menggunakan teori-teori yang telah didapat selama perkuliahan dan teori dari buku-buku penunjang.
\end{abstract}

Kata kunci: Sistem Informasi, Tanaman Hias, Pohon Pelindung

\section{PENDAHULUAN}

Dinas Kebersihan dan Pertamanan (DKP) Kota Pariaman merupakan salah satu dari dinas yang ada dilingkungan Pemerintah Kota Pariaman. Sebagai unsur pelaksana, kantor DKP Pariaman dipimpin oleh seorang Kepala Dinas.

Sering terjadinya pohon tumbang yang disebabkan oleh faktor cuaca dan usia pohon. Apalagi saat memasuki musim penghujan, tidak jarang hal ini sering menimbulkan korban jiwa serta menggangu kenyamanan pengguna jalan saat berkendara yang bisa menyebabkan kemacetan.

Hal ini membuat Dinas Pertamanan Kota Pariaman merevisi serta memanajemen kembali jenis pohon pelindung kota yang bisa dijadikan pelindung tapi tidak berbahaya. Rata- rata pohon pelindung kota yang sudah tua, ketika ada yang tumbang petugas harus mengganti dengan tanaman baru. Namun permasalahnnya adalah petugas harus menentukan pohon yang tepat untuk ditebang, maka beberapa tahun kedepan pohon tersebut nantinya tidak menimbulkan korban jiwa. 
Selain pohon, jenis tanaman hias pun harus dipilih yang menarik namun tidak mengganggu pengguna jalan.

Dinas Kebersihan dan Pertamanan Kota Pariaman memiliki permasalahan, yaitu penentuan jenis tanaman dan pohon pelindung secara manual masih memungkinkan terjadinya kesalahan dalam penentuan pemilihan tanaman yang menyebabkan tanaman mati karena tidak sesuai atau tidak cocok dengan kriteria tempat hidupnya. Laporan data belum terstruktur sehingga kurang efektif dan efisien. Untuk itu dibangun sebuah Sistem Informasi pengolahan data tanaman hias dan pohon pelindung di taman Kota Pariaman yang akan memudahkan pimpinan dalam menentukan jenis tanaman dan pohon pelindung.

\section{METODE PENELITIAN}

Menurut (Sutabri, 2012: 10) bahwa sistem dapat diartikan sebagai "suatu kumpulan atau himpunan dari unsur, komponen, atau variabel yang terorganisir, saling berinteraksi, saling bergantung satu sama lain, dan terpadu". Sedangkan menurut (Syahbana, 2011: 12) sistem merupakan "suatu jaringan kerja dari prosedur-prosedur yang saling berhubungan, berkumpul bersama-sama untuk melakukan suatu kegiatan atau untuk menyelesaikan suatu sasaran yang tertentu".

Penelitian ini menggunakan metode System Development Life Cycle (SDLC) yang terdiri dari empat langkah utama, yaitu perencanaan, analisis, perancangan, dan implementasi.

\section{a. Perencanaan Sistem}

Fase perencanaan adalah proses dasar untuk memahami alasan sebuah sistem harus dibangun, serta menentukan tujuan dan sasaran yang ingin dicapai. Perencanaan sistem yang dilakukan dalam penelitian ini adalah merencanakan aplikasi apa yang dipilih dalam pengembangan sistem.

b. Analisis Sistem

Fase analisa adalah sebuah proses investigasi terhadap sistem yang sedang berjalan dengan tujuan untuk mendapatkan jawaban mengenai penggunaan sistem, cara kerja sistem dan waktu penggunaan sistem.
Dari proses analisa ini akan didapatkan cara untuk membangun sistem baru.

Setelah dilakukan penganalisasian terhadap sistem informasi Dinas Pertamanan Kota Pariaman dalam proses penentuan jenis tanaman hias dan pohon pelindung, cara kerja dari pemilihan tanaman tersebut belum terkomputerisasi dengan alur kerja sebagai berikut:

1. Instansi pemerintahan menyerahkan surat perintah pembuatan taman kepada sekretaris.

2. Sekretaris mendisposisikan surat, kemudian diserahkan kepada pimpinan.

3. Pimpinan melakukan pemeriksaan dan meng-acc surat tersebut, surat yang telah di acc tersebut diserahkan kepada petugas bidang pertamanan.

4. Petugas bidang pertamanan melakukan pembuatan taman, hasil taman yang telah ditanam di foto. Foto taman yang telah selesai diserahkan kepada pimpinan.

5. Pimpinan memeriksa laporan dan foto taman, laporan dan foto taman diserahkan kepada sekretaris.

6. Sekretaris membuat surat pemberitahuan sebanyak 2 rangkap, 1 rangkap diserahkan kepada instansi pemerintahan, sisanya diarsip oleh sekretaris.

Berdasarkan penelitian yang telah penulis lakukan pada Dinas Pertamanan Kota Pariaman, ada beberapa kelemahan pada sistem yang sedang berjalan diantaranya sebagai berikut:

1.Penentuan jenis tanaman hias dan pohon pelindung masih dilakukan berdasarkan pengalaman (manual) saja, sehingga tak jarang tanaman yang ditanam tidak cocok di daerah tersebut menjadi tidak produktif atau mati.

2. Dalam hal penyimpanan data belum menggunakan database, sehingga keamanan data kurang terjamin dan proses pengambilan data menjadi lebih sulit dan lambat.

3. Dalam pembuatan laporan masih menggunakan Excel, sehingga dalam hal penyajian informasi tidak efisien dan membutuhkan waktu yang cukup lama dalam hal pemrosesannya. 
4. Tidak adanya laporan yang diarsip oleh pimpinan dalam pembuatan taman kota, sehingga pimpinan tidak mengetahui secara detail taman-taman yang telah ditanam.

Adapun analisis sistem berdasarkan keuntungan-keuntungan dari perubahan dan pengolahan data sistem pada DKP Kota Pariaman sebagai berikut:

1. Pemilihan jenis tanaman hias dan pohon pelindung sudah terkomputerisasi, sehingga tanaman yang ditanam cocok didaerah tersebut

2. Proses pengolahan data pemilihan tanaman hias dan pohon pelindung menggunakan suatu aplikasi berbasis database, sehingga menghasilkan laporan - laporan yang lebih cepat dan akurat, dan dapat melakukan pencarian data atau penyimpan data sehingga keakuratan data lebih terjamin.

3. Kemungkinan data hilang atau pun rusak lebih minim ketimbang menggunakan sistem lama dalam pengarsipan berkas.

c. Perancangan Sistem

Fase perancangan merupakan proses penentuan cara kerja sistem dalam hal spesifikasi file dan program design.
Menurut (Rusdiana dan Irfan, 2014: 34) basis data adalah "susunan record data operasional lengkap dari suatu organisasi atau perusahaan, yang diorganisasi dan disimpan secara terintegrasi dengan menggunakan metode tertentu sehingga mampu memenuhi informasi yang optimal yang dibutuhkan oleh para pengguna".

Perencanaan dilakukan menggunakan Hierarchy Input Process Output (HIPO), context diagram (CD), data flow diagram (DFD) dan entity relationship diagram (ERD).

\section{Hierarchy Plus Input-Process- Output (HIPO ) \\ HIPO merupakan metodologi yang} dikembangkan dan didukung, sebenarnya alat dokumentasi program yang sekarang banyak digunakan sebagai alat desain dan teknik dokumentasi dalam siklus pengembangan sistem, berbasis pada fungsi yaitu tiap-tiap modul dalam sistem digambarkan oleh fungsi utamanya.

HIPO yang dirancang untuk rancangan sistem informasi pengoalahan data tanaman hias dan pohon pelindung di taman Kota Pariaman dapat dilihat pada Gambar 1.

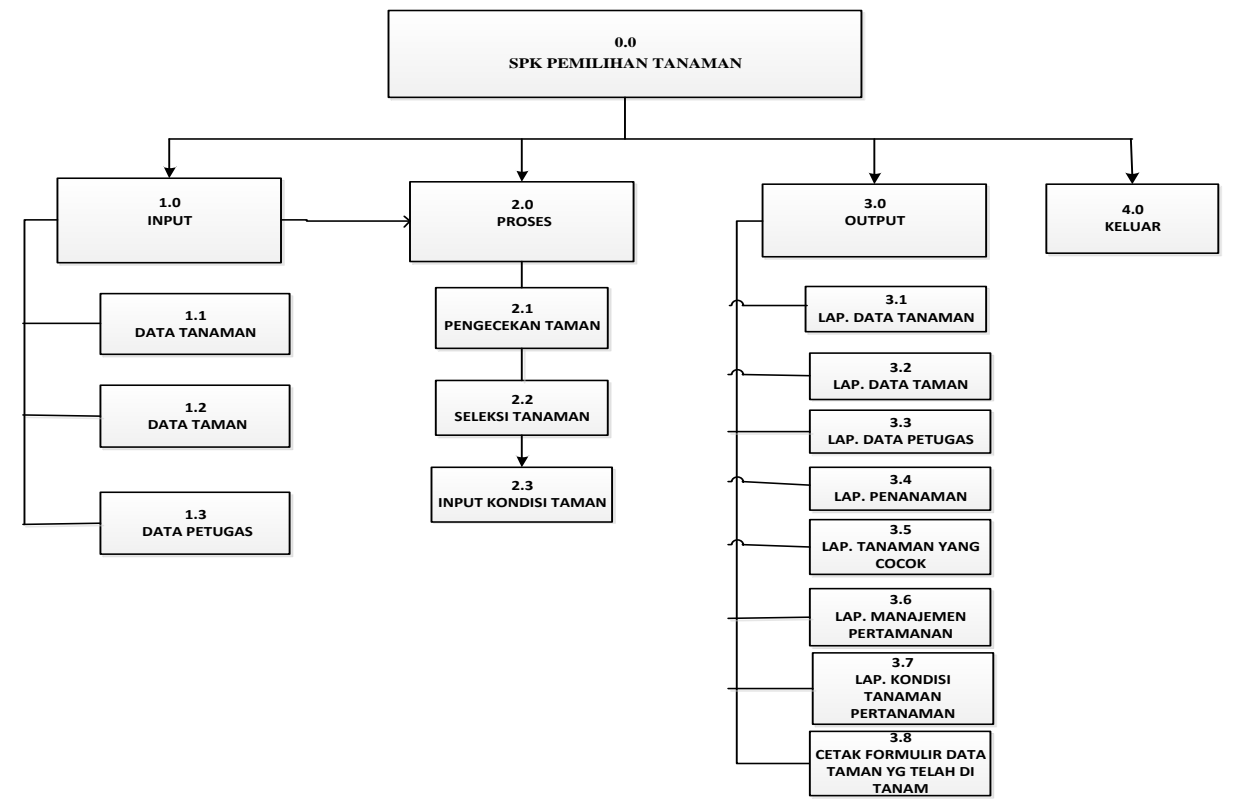

Gambar 1. Hierarchy Plus Input-Process- Output

\section{Context Diagram (DFD Level Nol)}

Menurut (Al-Bahra Bin Ladjamudin, 2013: 10) DFD adalah "representasi grafik menggambarkan aliran sistem informasi dan transformasi informasi yang diaplikasikan sebagai data yang mengalir dari masukan (input) dan keluaran (output)".

Context Diagram adalah diagram yang terdiri dari suatu proses dan 
menggambarkan ruang lingkup suatu sistem. Diagram konteks merupakan level tertinggi dari DFD yang menggambarkan seluruh input ke sistem atau output dari sistem. Ia akan memberi gambaran tentang keseluruhan sistem. Sistem dibatasi oleh boundary (dapat digambarkan dengan garis putus). Dalam diagram konteks hanya ada satu proses. Context Diagram sistem informasi pengolahan data tanaman hias dan pohon pelindung di taman Kota Pariaman dapat dilihat pada Gambar 2.

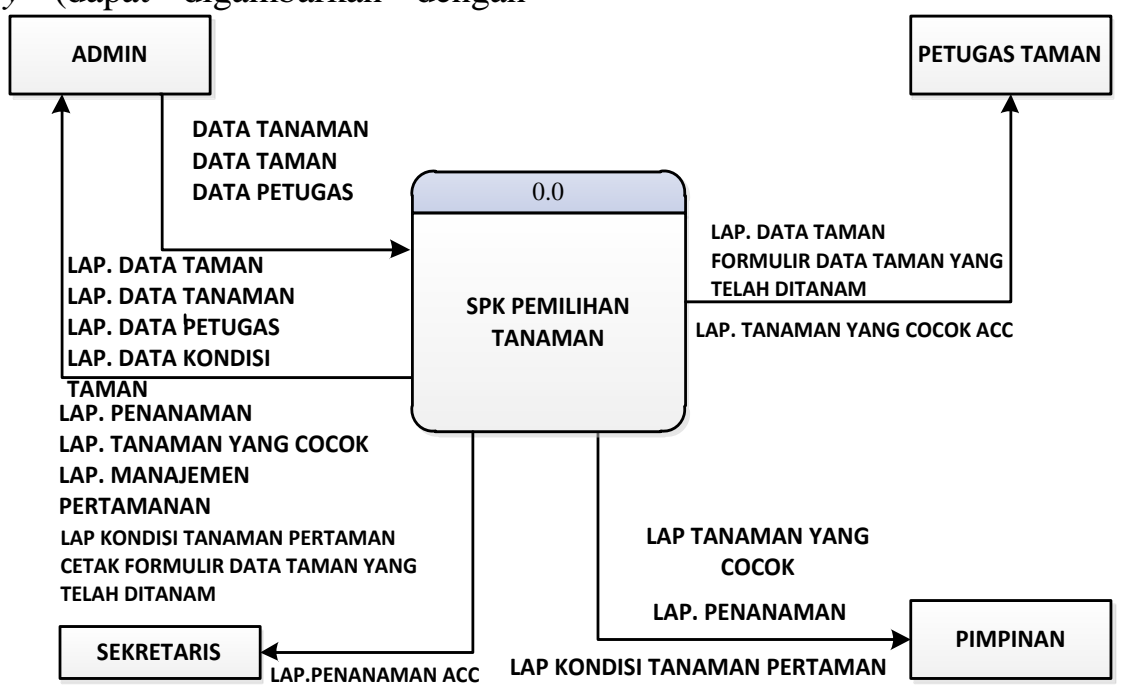

Gambar 2. Context Diagram

DFD (Data Flow Diagram)Level 1

Berikut ini adalah Data Flow Diagram (DFD) dari sistem informasi pengolahan data tanaman hias dan pohon pelindung ditaman Kota Pariaman, dimana DFD ini diuraikan diuraikan berdasarkan Contex
Diagram yang telah dijabarkan sebelumnya pada Gambar 2.

DFD ini juga terdiri dari beberapa entity yaitu admin, sekretaris, petugas taman dan pimpinan dapat dilihat pada Gambar 3.

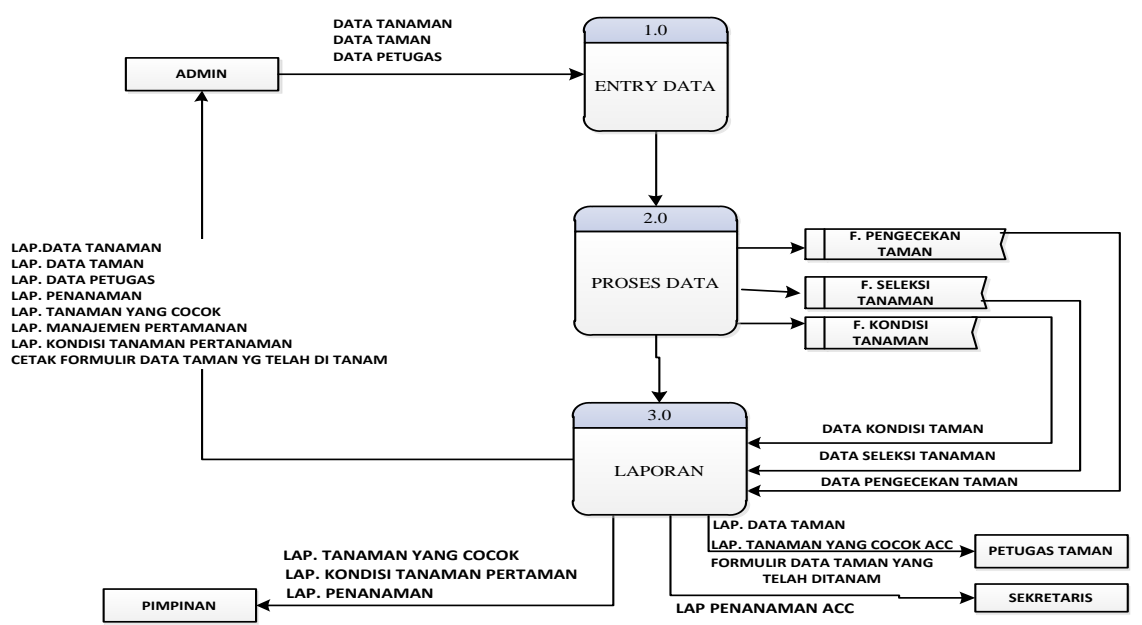

Gambar 3. Data Flow Diagram Level 1

Entity Relationship Diagram (ERD)

Entity Relationship Diagram menggambarkan hubungan atau relasi antara atribut-atribut yang terdapat pada konseptual sistem secara berbeda yang terdiri dari entity atribut-atribut yang ada. Bentuk entity relationship diagram yang digunakan dapat dilihat pada Gambar 4. 


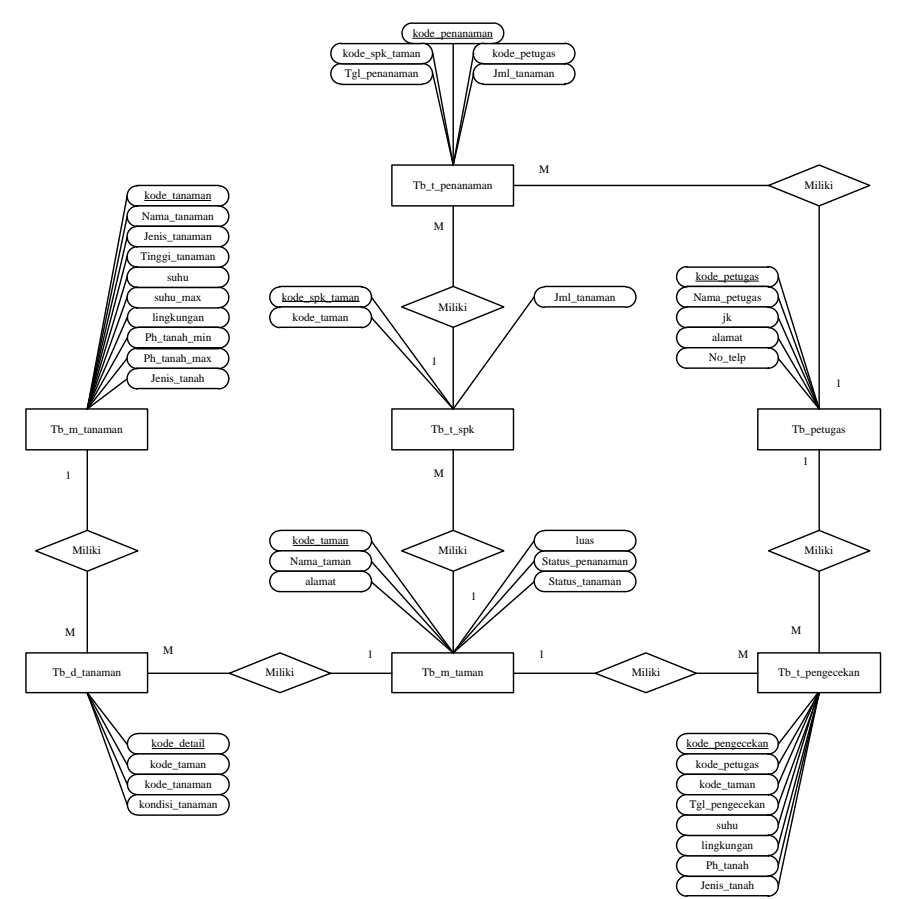

Gambar 4. Entity Relationship Diagram

d. Implementasi Sistem

Fase implementasi adalah proses pembangunan, pengujian, instalansi dan dukungan sistem. Pada tahap ini dilakukan implementasi dengan aplikasi yang dibuat.

\section{HASIL}

\section{Menu Login}

Halaman login bertujuan untuk membatasi hak akses pengguna atau user dalam menggunakan sistem. Berarti sistem hanya dapat digunakan oleh user tertentu yang sudah dikenal sistem.Tampilan halaman login user dapat dilihat pada Gambar 5.

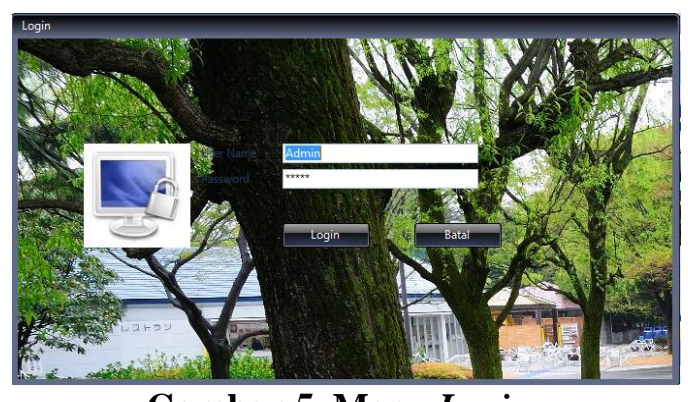

Gambar 5. Menu Login

2. Menu Utama
Menu utama merupakan tampilan awal dari sistem atau program yang akan diimplementasikan pada sistem pengolahan data. Tampilan menu utama dapat dilihat pada Gambar 6.

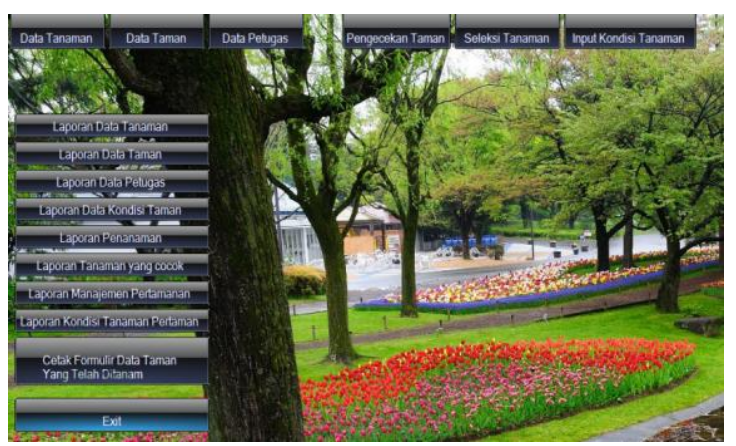

Gambar 6. Menu Utama

Menu utama terdiri dari: Entry Data yaitu: data tanaman, data taman, data petugas. Pada proses data terdiri dari seleksi tanaman, pengecekan taman dan input kondisi taman, beserta laporan terdiri dari laporan data tanaman, laporan data taman, laporan data petugas, laporan data kondisi taman, laporan penanaman, laporan tanaman yang cocok, laporan manajemen pertamanan dan laporan 
kondisi tanaman pertaman. Menu terakhir adalah Logout untuk menutup aplikasi.

3.

Menu Laporan

Menu Laporam terdiri dari modul laporan data tanaman, laporan data taman, laporan data petugas, laporan data kondisi taman, laporan penanaman, laporan taman selesai dikerjakan, laporan manajemen pertamanan dan laporan kondisi tanaman pertaman.

a.

\section{Laporan Data Tanaman}

Menu laporan ini berfungsi untuk mengetahui tanaman yang ada pada DKP Kota Pariaman, Laporan data tanaman dapat dilihat pada Gambar 7.

\begin{tabular}{|c|c|c|c|c|c|c|c|c|c|c|}
\hline \multirow[b]{2}{*}{ № } & \multirow{2}{*}{ 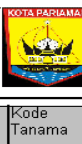 } & DINAS K & EBER & $\begin{array}{l}\text { IHHAN I } \\
\text { onegoro No } \\
\text { LAPOI }\end{array}$ & AN P & $\begin{array}{l}\text { ZRTA } \\
\text { Pondo }\end{array}$ & $\begin{array}{l}\text { MANAN } \\
\text { ariaman Teng } \\
\text { NAMAN }\end{array}$ & PTA & ARIA & IAN \\
\hline & & $\begin{array}{l}\text { Nama } \\
\text { Tanaman }\end{array}$ & \begin{tabular}{|l|} 
Jenis \\
Tanaman
\end{tabular} & $\begin{array}{l}\text { Tinggi } \\
\text { Tanaman }\end{array}$ & \begin{tabular}{|l} 
Suhu \\
Min
\end{tabular} & $\begin{array}{l}\text { Suhu } \\
\text { Max }\end{array}$ & Lingkungan & $\begin{array}{l}\text { Ph } \\
\text { Tanah }\end{array}$ & $\begin{array}{c}\text { Ph } \\
\text { Tanah }\end{array}$ & $\begin{array}{l}\text { Tenis } \\
\text { Tanah }\end{array}$ \\
\hline 1 & TN-0001 & Agave & Hias & 40 & 29 & 30 & Panas & 6 & 6 & Aluvium \\
\hline 2 & TN-000z & Airis & Hias & 40 & 27 & 27 & Sejuk & 6 & 7 & Podzoid \\
\hline 3 & TN-000三 & Akalifah & Hias & 20 & 27 & 28 & Panas & 7 & 7 & Aluvium \\
\hline 4 & TN-0004 & Asoka Daun Bes & Hias & 40 & 29 & 30 & Panas & 6 & 6 & Aluvium \\
\hline 5 & TN-000E & Alamanda & Hias & 40 & 27 & 27 & Sejuk & 7 & 7 & Humus \\
\hline 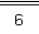 & $\begin{array}{l}T N-000 E \\
\end{array}$ & Asoka Jepang & Hias & 30 & 29 & 30 & Panas & 7 & 7 & Humus \\
\hline 7 & TN-0007 & Asoka Mini & Hias & 20 & 27 & 27 & Sejuk & 6 & 7 & Humus \\
\hline 8 & TN-000E & Asparagus & Hias & 40 & 27 & 27 & Sejuk & 5 & 6 & Humus \\
\hline 9 & TN-000E & Bakung & Hias & 30 & 27 & 27 & Sejuk & 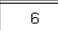 & 6 & Humus \\
\hline 10 & TN-001C & Bambu Jepang & Hias & 50 & 26 & 26 & Sejuk & 7 & 7 & Humus \\
\hline 11 & TN-0011 & Barmolia & Hias & 20 & 26 & 27 & Sejuk & 5 & 6 & Gambut \\
\hline
\end{tabular}

Gambar 7. Laporan Data Tanaman

\section{b. Laporan Data Taman}

Menu laporan data taman merupakan data taman-taman yang ada pada wilayah Kota Pariaman, disana dapat kita ketahui alamat dan luas taman tersebut. Untuk lebih jelasnya dapat dilihat pada Gambar 8.

\begin{tabular}{|c|c|c|c|c|}
\hline \multicolumn{2}{|c|}{$\infty$} & \multicolumn{3}{|c|}{$\begin{array}{l}\text { J1. Diponegoro No } 48 \text {, Kampung Pondok Pariaman Tengah, } \mathrm{F} \\
\text { LAPORAN DATA TAMAN }\end{array}$} \\
\hline No & Kode Taman & Nama Taman & Alamat Taman & luas \\
\hline 1 & \begin{tabular}{|l|l|l} 
TM-0001 \\
\end{tabular} & Taman Lapangan merdeka & \begin{tabular}{|l|l} 
J1. Jend Sudirman \\
\end{tabular} & 300 \\
\hline 2 & \begin{tabular}{|l|l} 
TM-0002 \\
\end{tabular} & Taman Median Road & J1. Imam Bonjol & 400 \\
\hline 3 & TM-0003 & Taman Pendopo W alikota & \begin{tabular}{|l|} 
Rumah Dinas W alikota \\
\end{tabular} & 30 \\
\hline 4 & \begin{tabular}{|l|} 
TM-0004 \\
\end{tabular} & T aman Pendopo W akil Wa alikota & Rumah Dinas Wakil Walikota & 30 \\
\hline 5 & TM-0005 & Taman terminal jati & J1. WR Mongonsidi & 250 \\
\hline 6 & TM-0006 & Taman rumah tabuik subarang & J1. Imam Bonjol & 200 \\
\hline 7 & TM-0007 & Taman kantor Walikota & J1. Imam Bonjol & 30 \\
\hline 8 & TM-0008 & Taman rumah tabuik pasa & J1. Syech Burhanuddin & 40 \\
\hline 9 & TM-0009 & Taman pantai Gandoriah & J1. Syech Burhanuddin & 40 \\
\hline 10 & TM-0010 & Taman Anas Malik & J1. Syech Burhanuddin & 50 \\
\hline
\end{tabular}

Gambar 8. Laporan Data Taman 


\section{c. Laporan Data Pekerja}

Menu laporan data pekerja merupakan laporan yang berisikan semua data para pekerja yang ada pada DKP

Kota Pariaman. Untuk lebih jelasnya dapat dilihat pada Gambar 9.

\begin{tabular}{|l|l|c|l|l|}
\hline \multicolumn{5}{|c|}{ DINAS KEBERSIHAN DAN PERTAMANAN KOTA PARIAMAN } \\
\multicolumn{5}{|c|}{ LA. Diponegoro No 48, Kampung Pondok Pariaman Tengah, Pariaman } \\
\hline \multicolumn{5}{|c|}{ LAPAN DATA PEKERJA } \\
\hline Kode Pekerja & Nama Pekerja & Jenis Kelamin & \multicolumn{2}{c|}{ Alamat } \\
\hline \hline PT-0001 & Feriyadi & Laki - Laki & Desa Taluk & 082390161510 \\
\hline PT-0002 & Masrizal Enek & Laki - Laki & Desa Pauh Timur & 081267886788 \\
\hline PT-0003 & Syahrizal & Laki - Laki & Desa Pauh Timur & 085364838316 \\
\hline PT-0004 & Mukhtamar & Laki - Laki & Desa Sunur & 085278529531 \\
\hline PT-0005 & Arizal & Laki - Laki & Desa Taluk & 081267565432 \\
\hline PT-0006 & Ariz Munandar & Laki - Laki & Desa Sunur & 082390908765 \\
\hline PT-0007 & Syamsudin & Laki - Laki & Desa Taluk & 085278621278 \\
\hline PT-0008 & Donni putra & Laki - Laki & Desa Sunur & 089657885847 \\
\hline PT-0009 & Zainudin & Laki - Laki & Desa Bungo Tanjung & 081264785431 \\
\hline PT-0010 & Ahmad Ari & Laki - Laki & Desa Kampung Tangah & 082388101167 \\
\hline
\end{tabular}

Gambar 9. Laporan Data Pekerja

\section{d. Laporan Kondisi Taman}

Menu laporan kondisi taman merupakan daftar taman yang akan ditanami tanaman. Didalamnya terdapat alamat, suhu, lingkungan, $\mathrm{Ph}$ tanah dan jenis tanah yang telah diambil oleh petugas pengecekan taman sebelumnya. Untuk lebih jelasnya dapat dilihat pada Gambar 10.

\section{DINAS KEBERSIHAN DAN PERTAMANAN KOTA PARIAMAN}

J1. Diponegoro No 48, Kampung Pondok Pariaman Tengah, Pariaman

LAPORAN KONDISI TANAMAN PERTAMAN

$$
\begin{array}{lll}
\text { Kode Taman } & : & \text { TM-0001 } \\
\text { Nama Taman } & : & \text { Taman Lapangan merdeka } \\
\text { Alamat } & : & \text { Jl. Jend Sudirman } \\
\text { Luas } & : & 300 \quad \text { Meter Persegi }
\end{array}
$$

\begin{tabular}{|c|l|l|l|l|}
\hline No & Kode Tanaman & Nama Tanaman & Jenis Tanaman & Kondisi Tanaman \\
\hline \hline 1 & $\mathrm{TN}-0003$ & Akalifah & Hias & Mati \\
\hline 2 & $\mathrm{TN}-0022$ & Hanjung Merah K & Hias & Mati \\
\hline 3 & $\mathrm{TN}-0027$ & Kaliandra & Hias & Subur \\
\hline A & TN_nnz2 & Krnknt Duttih & Hise & Suhur \\
\hline
\end{tabular}

\section{Gambar 10. Laporan Kondisi Taman}

\section{e. Laporan Penanaman}

Menu laporan penanaman merupakan laporan taman yang telah selesai ditanamUntuk lebih jelasnya dapat dilihat pada Gambar 11. 
DINAS KEBERSIHAN DAN PERTAMANAN KOTA PARIAMAN

J1. Diponegoro No 48, Kampung Pondok Pariaman Tengah, Pariaman

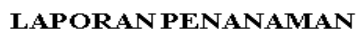

\begin{tabular}{|c|l|l|l|l|l|l|l|r}
\hline \hline No & $\begin{array}{l}\text { Kode } \\
\text { Penanaman }\end{array}$ & $\begin{array}{l}\text { Tgl } \\
\text { Penanaman }\end{array}$ & Nama Petugas & $\begin{array}{l}\text { Kode } \\
\text { Taman }\end{array}$ & Nama Taman & $\begin{array}{l}\text { Alamat } \\
\text { Taman }\end{array}$ & $\begin{array}{l}\text { Luas } \\
\text { (Meter } \\
\text { Persegi) }\end{array}$ & $\begin{array}{l}\text { Jml } \\
\text { Tanaman }\end{array}$ \\
\hline 1 & PN-0001 & $10-$ Oct-2016 & Ariz Munandar & TM-0002 & $\begin{array}{l}\text { Taman Median } \\
\text { Road }\end{array}$ & J1. Imam Bonjo1 & 400 & 30 \\
\hline \hline 2 & PN-0002 & $10-$ Oct-2016 & Ariz Munandar & TM-0004 & $\begin{array}{l}\text { Taman Pendopo } \\
\text { Wakil Walikota }\end{array}$ & $\begin{array}{l}\text { Rumah Dinas } \\
\text { Wakil Walikota }\end{array}$ & 30 & 39 \\
\hline \hline 3 & PN-0003 & $10-$-Oct-2016 & Ariz Munandar & TM-0003 & $\begin{array}{l}\text { Taman Pendopo } \\
\text { Walikota }\end{array}$ & $\begin{array}{l}\text { Rumah Dinas } \\
\text { Walikota }\end{array}$ & 30 & 31 \\
\hline \hline 4 & PN-0004 & $13-$-Oct-2016 & Syamsudin & TM-0006 & $\begin{array}{l}\text { Taman rumah } \\
\text { tabuik subarang }\end{array}$ & J1. Imam Bonjo1 & 200 & 16 \\
\hline \hline 5 & PN-0005 & $13-$ Oct-2016 & Syamsudin & TM-0009 & $\begin{array}{l}\text { Taman pantai } \\
\text { Gandoriah }\end{array}$ & $\begin{array}{l}\text { J1. Syech } \\
\text { Burhanuddin }\end{array}$ & 40 & 2 \\
\hline \hline 6 & PN-0006 & $13-$ Oct-2016 & Syamsudin & TM-0010 & $\begin{array}{l}\text { Taman Anas } \\
\text { Malik }\end{array}$ & $\begin{array}{l}\text { J1. Syech } \\
\text { Burhanuddin }\end{array}$ & 50 & 39 \\
\hline
\end{tabular}

Gambar 11. Tampilan Laporan Penanaman

\section{f. Laporan Tanaman yang Cocok}

Menu laporan tanaman yang cocok merupakan hasil seleksi dari proses seleksi tanaman dengan kriteria yang telah terpenuhi, yang mana kriteria suhu, lingkungan, jenis tanah dan $\mathrm{Ph}$ tanah telah terpenuhi. Lebih jelasnya dapat dilihat pada Gambar 12.

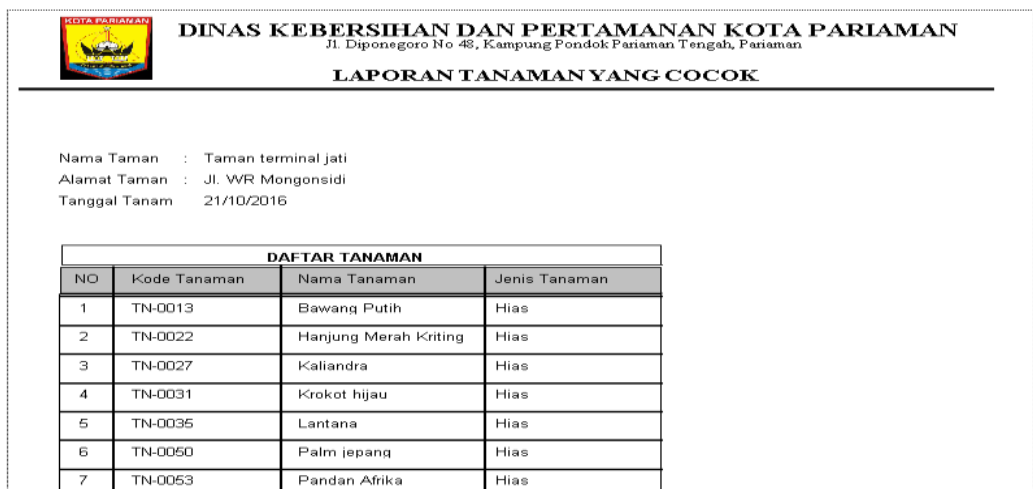

Gambar 12. Laporan Tanaman yang Cocok

\section{g. Laporan Manajemen} Pertamanan

Menu manajemen semua data taman yang ada diwilayah pariaman baik yang baru saja selesai ditanam serta taman yang sudah ada. Didalamnya terdapat data taman serta daftar tanaman yang terdapat pada taman tersebut. Tampilannya dapat dilihat pada Gambar 13. 


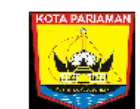

DINAS KEBERSIHAN DAN PERTAMANAN KOTA PARIAMAN

J1. Diponegoro No 48, Kampung Pondok Pariaman Tengah, Pariaman LAPORAN DATA MANAJEMEN TAMAN KOTA

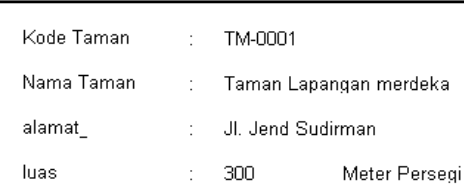

\begin{tabular}{|c|l|l|l|}
\hline \multicolumn{4}{|c|}{ DAFTAR TANAMAN } \\
\hline No & kode_tanaman & nama_tanaman & ienis tanaman \\
\hline \hline 1 & TN-0003 & Akalifah & Hias \\
\hline \hline 2 & TN-0022 & Haniung Merah Kritin & Hias \\
\hline \hline
\end{tabular}

Gambar 13. Tampilan Laporan Manajemen Pertamanan

h. Laporan Kondisi

Tanaman Pertaman

Menu laporan kondisi

tanaman pertaman

merupakan laporan untuk

mengetahui kondisi

tanaman yang setelah

selesai ditanam dengan rentan waktu satu bulan setelah tanaman selesai ditanam, kategori kondisi tanaman tersebut adalah subur, layu atau mati. Tampilannya dapat dilihat pada Gambar 14.

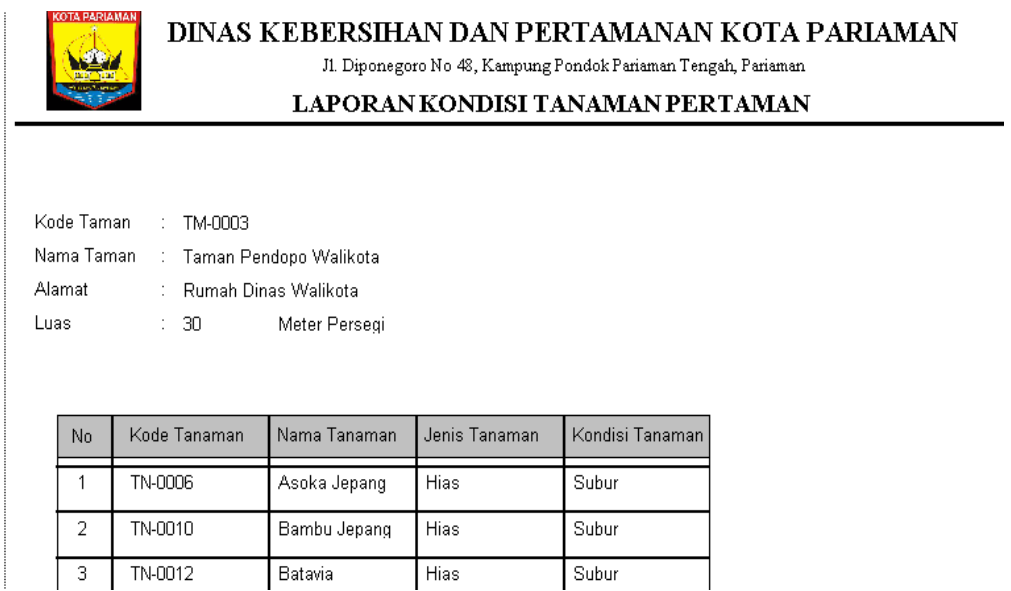

Gambar 14. Tampilan Laporan Kondisi Tanaman Pertaman

i. Cetak Formulir

Taman yang Telah

Ditanam

Menu cetak formulir taman yang telah ditanam berfungsi untuk pengambilan data kondisi tanaman secara manual oleh petugas pertamanan yang telah ditanam dalam rentan waktu sebulan setelah penanaman. Tampilannya dapat dilihat pada Gambar 15. 


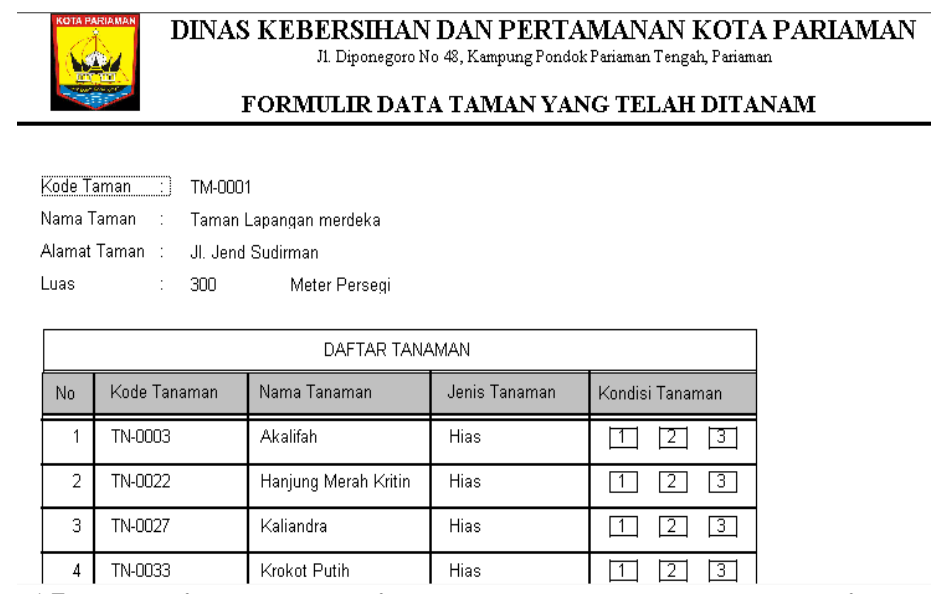

\section{Gambar 15. Tampilan Formulir Data Taman yang Telah Ditanam}

\section{SIMPULAN}

Berdasarkan penelitian dan analisa yang dilakukan pada DKP Kota Pariaman mengenai penentuan jenis tanaman yang akan di tanam pada taman Kota Pariaman, maka dapat diambil kesimpulan sebagai berikut:

1. Dengan adanya sistem informasi pengolahan data tanaman, dapat meminimalisir kemungkinan terjadinya ketidakcocokan pada tanaman karena tanaman yang dipilih telah sesuai dengan kriteria tempat hidup taman tersebut.

2. Sistem ini dapat mempermudah dalam pembuatan laporan karena telah dilakukan secara terkomputerisasi, sehingga lebih efektif dan efisien dalam segi waktu, biaya dan tenaga.

3. Dengan menggunakan bahasa pemograman Visual dan database manajemen sistem sebagai database, akan membawa keuntungan bagi Dinas Kebersihan dan Pertamanan Kota Pariaman karena akan memudahkan proses pengambilan keputusan untuk penentuan jenis tanaman.

\section{DAFTAR PUSTAKA}

Al-Bahra Bin Ladjamudin. 2013. Analisis Dan Desain Sistem Informasi. Yogyakarta: Graha ilmu.

Rusdiana dan Irfan Moch. 2014. Sistem Informasi Manajemen. Bandung: Penerbit Pustaka Setia.
Sutabri, Tata. 2012. Konsep Sistem Informasi. Yogyakarta: PenerbitAndi Offset.

Syahbana. 2011. Sistem Informasi Akademik Berbasis Multimedia Pada Lembaga Pendidikan Palembang Technology. Jurnal Teknologi dan Informatika (Teknomatika) Vol.1 No. 2. 